\title{
ORAL MANIFESTATIONS OF CROHN'S DISEASE: A CASE REPORT
}

\author{
Muhvic Urek Miranda, ${ }^{1}$ Mijandrusic Sincic Brankica, ${ }^{2}$ Braut Alen ${ }^{3}$ \\ ${ }^{1}$ Department of Oral Medicine, Dental Clinic, University Hospital Rijeka, Croatia \\ ${ }^{2}$ Division of Gastroenterology, Department of Internal Medicine, University Hospital Rijeka, Croatia \\ ${ }^{3}$ Department of Restorative Dentistry and Endodontics, Dental Clinic, University Hospital Rijeka, Croatia
}

Primljen/Received 28. 08. 2015. god.

Prihvaćen/Accepted 09. 10. 2015. god.

Abstract: Crohn's disease is a chronic inflammatory bowel disease still with unknown etiology. In $0.5-20 \%$ of patients, extra intestinal lesions in the oral cavity can be presented in forms of orofacial granulomatosis, cobblestone and corrugated oral mucosa, mucosal tags, deep linear ulcerations with hyperplastic folds, pyostomatits vegetans, aphthous ulcers, angular cheilitis, labial/facial edema and gingival erythema/edema. We describe a case of a 28 -year-old male who was presented with oral lesions of Crohn's disease and treatment procedure. The patient was candidate for biologic treatment so dental procedures and preparation of the patient for treatment are described. Good communication and cooperation between the patient's doctor and dentist are important for successful treatment.

Key words: Crohn's disease; inflammatory bowel disease; oral manifestation.

\section{INTRODUCTION}

Crohn's disease (CD) is a chronic inflammatory granulomatous disease with primary intestinal involvement but it may involve any part of bowel system from mouth to anus $(1,2)$.

The etiology of disease is still unknown but genetic factor, environmental factors and immune response in the bowel wall seems to be main causes of $\operatorname{CD}(3,4)$.

The disease is characterized by phases of exacerbation and remission, with the symptoms of diarrhea, stomach pain, weight loss and elevated body temperature $(1,5)$. One third of patients can exhibit extra intestinal manifestations of the disease (6). The most frequent manifestations affect the joints, skin, eyes and hepatobiliary system. Changes in the oral cavity, blood vessels, heart, lungs and genitourinary and endocrine system have been also described $(6,7)$.

Oral lesions of CD were first described in 1969 by Dyer at al (8). In the same year Dudeney (9) reported another case of patient suffering from $\mathrm{CD}$ who had oral manifestations. The prevalence rate of oral manifestations is estimated to be between 0.5 to $20 \%(5,10,11)$, although some studies mention up to $80 \%(12,13)$. They include orofacial granulomatosis, cobblestone and corrugated oral mucosa, mucosal tags, deep linear ulcerations with hyperplastic folds, pyostomatitis vegetans, aphthous ulcers, angular cheilitis, labial/facial edema and gingival erythema/edema $(10,14,15)$. Presence of cobblestone mucosa and mucosal tags are highly suggestive to $\mathrm{CD}$ (16).

There is a male predilection and the oral outbreaks often start in young ages (17). Up to $60 \%$ of patients with $\mathrm{CD}$ may present oral manifestations years before the appearance of intestinal disease $(5,17)$. Oral manifestations are unpleasant bitter, disagreeable, displeasing, and distasteful for the patients; restrict their nutrition and oral hygiene.

The aim of this paper is to present a case of patient with oral manifestation of $\mathrm{CD}$ and treatment procedure.

\section{CASE REPORT}

A 28-years-old male patient was referred to the Department of Oral medicine at the Dental clinic Rijeka due to pain in the mouth. Oral complains and lesions have been presented for 10 days.

The patient medical history revealed that he has been suffering from $\mathrm{CD}$ for five years. He has been subjected to resection of terminal ileum and sigmoid colon in 2010. Post-surgical remission was maintained with azathioprine therapy for four years. Two months after stopping the azathioprine therapy, (four months prior of arrival in our clinic) the disease became active and the infliximab was recommended. During the period of patient's preparation for infliximab therapy the patient was referred to the Oral medicine Dental Office for treating lesions in the oral cavity and excluding oral 
foci of infection. He has never before experienced oral lesions since he was diagnosed with $\mathrm{CD}$.

Clinical exam revealed erythema and inflammation with white to yellow small pustules on the right buccal mucosa, what was recognized as pyostomatitis vegetans. Furthermore, in the lower right quadrant on the vestibular gingiva and in the fornix a thickened, inflamed and cobblestone oral mucosa with ulcerations was presented (Figure 1). Under local anesthesia (2\% lidocaine) an incision biopsy of the altered mucosa and gingiva was performed. Swabs were taken from the oral mucosa for the microbiological analysis.

Patient was prescribed a topical antiseptic therapy $(0.2 \%$ chlorhexidine gluconate solution three times per day), corticosteroid $(0.05 \%$ betamethasone ointment three times per day), and systemic corticosteroid (prednisolone $30 \mathrm{mg}$ ) with proton pump inhibitor.

On recall visit after seven days the sutures were removed. Clinically the erosions were epithelized and the inflammation diminished. The patient continued the prescribed therapy for additional 7 days. The biopsy of the buccal lesion revealed: dense lymphoma histiocytic inflammatory cell infiltration in the vicinity of the basal membrane. In the gingiva sample histiocytic granulomas were presented, that all together indicated the presence of Crohn's disease.

Patient's dental status was taken, vitality tests were performed, and the panoramic radiogram was analyzed. No pathological changes were found on the teeth or on the surrounding bone. Microbiological results were negative and from the dental point of view the patient was eligible to start the biologic therapy.

On the second recall after 14 days the oral mucosa was normal without pathological changes (Figure 2).

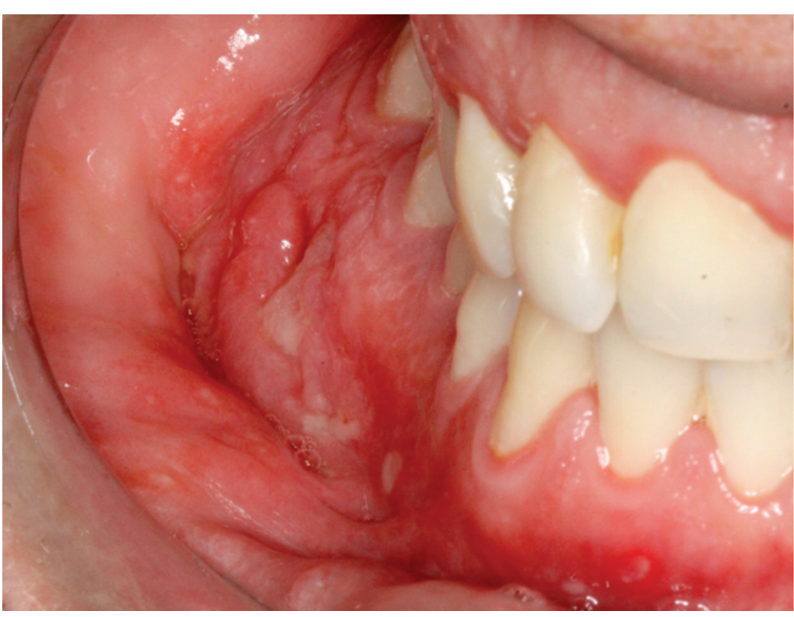

Figure 1. Clinical appearance at time of first presentation. White to yellow small pustules on the inflamed buccal mucosa and cobblestone lesions with ulcerations on the vestibular gingiva and in the fornix

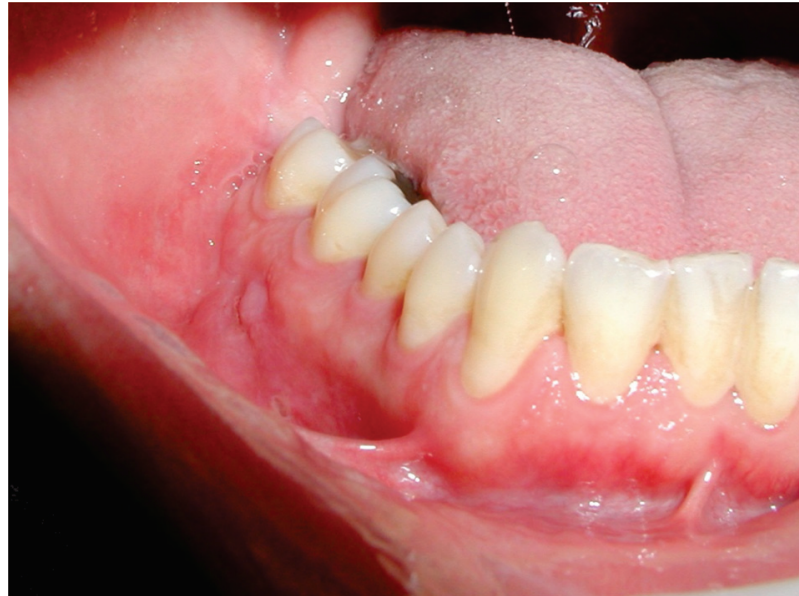

Figure 2. Clinical appearance at second recall. There was no oral lesions. The site of gingival biopsy is visible

Topical therapy was stopped while the systemic prednisolone therapy remained and it was gradually tapered down under gastroenterology specialist supervision. Patient was instructed to come for consult after one month, when there was no oral lesions presented.

After routine preparation for biologic (anti-TNF) therapy (screening for tuberculosis and viruses), infliximab induction therapy was administered by which the remission of Cohn's diseases was achieved. Infliximab maintenance therapy was continued by re-administration every eight weeks. Now, he is in stable remission.

\section{DISCUSSION}

We presented the case of a patient who developed oral manifestations of $\mathrm{CD}$ in the phase of reactivation of the disease, after interrupting of maintenance azathioprine therapy during four years.

Although, in the mouth of patients with $C D$ a vast variety of specific and nonspecific lesions can be presented, in our case the pyostomatitis vegetans, cobblestone mucosa and ulcerations were observed. In the literature it is reported that the oral lesions can appear either before, coincide, or after the onset of symptoms and lesions in the gastrointestinal system (17-21). The severity of oral lesions can indicate the activity level of chronic inflammatory processes in the intestine (22).

Oral lesion can be managed by topical corticosteroids such as triamcinolone acetonide and betamethasone (23). The topical application of corticosteroids sometimes is not sufficient and a systematic administration of corticosteroids is needed (e.g. prednisolone) $(23,24)$. Some authors state that the topical application of corticosteroids is not sufficient, and treatment must start from the beginning with systemic corticosteroid therapy (25). In the presented case, it was decided to start simultaneously with topical and systemic cortico- 
steroid therapy what resulted in healing of oral lesions. After 14 days the topical therapy was halted, while the systemic corticosteroid was gradually tapered down.

Administration of medium high and high doses of systematic corticosteroids results on disappearance of lesions, however the lowering of dosage or stopping the treatment can result in exacerbation of the lesions (26). For the modern therapy it is unacceptable to keep the patient in remission with corticosteroids due to numerous side effects. The azathioprine therapy that was administered for 4 years after withdrawal brought the patient to acute disease exacerbation including oral lesions. The anti-TNF therapy was the choice for our patient.

However, the initiation of biologic therapy requires strict preparation procedures including detection of manifest and hidden potential focal infections (27). The preparation includes exam of oral cavity and teeth (27). Patient have to present restored teeth, healthy periodontal tissue and oral mucosa, and the possible oral foci have to be eliminated. The presence of oral foci due to immunosuppressive action of the biologic therapy can lead to distant focal infections that can jeopardize the patient's health and life. Therefore, the dental exam was performed and the foci of oral origin were excluded in our patient.

\section{CONCLUSION}

In the presented case the findings in the oral cavity were manifestations of the primary disease and the patient was treated for the primary disease (with corticosteroids, and subsequently anti-TNF biologic medication). Since the patient was candidate for biologic therapy the foci of oral origin were excluded. For the successful treatment of extra intestinal/oral lesions of Cohn's disease good communication between gastroenterology specialist and the dentist/oral medicine specialist is essential.

\title{
Sažetak
}

\section{ORALNA MANIFESTACIJA KRONOVE BOLESTI — PRIKAZ SLUČAJA}

\author{
Muhvic Urek Miranda, ${ }^{1}$ Mijandrusic Sincic Brankica, ${ }^{2}$ Braut Alen ${ }^{3}$ \\ ${ }^{1}$ Department of Oral Medicine, Dental Clinic, University Hospital Rijeka, Croatia \\ ${ }^{2}$ Division of Gastroenterology, Department of Internal Medicine, University Hospital Rijeka, Croatia \\ ${ }^{3}$ Department of Restorative Dentistry and Endodontics, Dental Clinic, University Hospital Rijeka, Croatia
}

Kronova bolest je hronična zapaljenska bolest creva još uvek nepoznate etiologije. U 0,5-20\% pacijenata mogu se javiti ekstraintestinalne lezije u usnoj duplji u obliku orofacijalne granulomatoze, kaldrmaste i talasaste oralne sluznice, sluzničkih nabora, dubokih linearnih ulceracija s hiperplastičnim naborima, piostomatitis vegetansa, aftoznih ulceracija, angularnog heilitisa, otoka usana i lica te crvenila i otoka gingive. U ovom radu opi-

\section{REFERENCES}

1. Baumgart DC, Sandborn WJ. Crohn's disease. Lancet. 2012; 380(9853): 1590-605.

2. Fatahzadeh M, Schwartz RA, Kapila R, Rochford C. Orofacial Crohn's disease: an oral enigma. Acta Dermatovenerol Croat. 2009; 17(4): 289-300.

3. MacDonald TT, Monteleone G, Pender SL. Recent developments in the immunology of inflammatory bowel disease. Scand J Immunol. 2000; 51(1): 2-9.

4. Ponsky T, Hindle A, Sandler A. Inflammatory bowel disease in the pediatric patient. Surg Clin North Am. 2007; 87(3): 643-58.

5. Fatahzadeh M. Inflammatory bowel disease. Oral Surg Oral Med Oral Pathol Oral Radiol Endod. 2009; 108(5): 1-10.

6. Williams H, Walker D, Orchard TR. Extraintestinal manifestations of inflammatory bowel disease. Curr Gastroenterol Rep. 2008; 10(6): 597-605. san je slučaj 28-godišnjeg pacijenta koji je razvio oralne lezije u sklopu Kronove bolesti i postupak lečenja. Pacijent je bio kandidat za biološko lečenje te je u radu opisan stomatološki postupak pripreme pacijenta za lečenje. Za uspešno lečenje bitna je dobra komunikacija i saradnja između pacijentovog doktora i stomatologa.

Ključne reči: Kronova bolest; Oralne manifestacije; zapaljenska bolest creva.

7. Vavricka SR, Rogler G, Gantenbein C at al. Chronological Order of Appearance of Extraintestinal Manifestations Relative to the Time of IBD Diagnosis in the Swiss Inflammatory Bowel Disease Navarini AA Cohort. Inflamm Bowel Dis. 2015; 21(8): 1794-800.

8. Dyer NH, Cook PL, Kemp Harper RA. Oesophageal stricture associated with Crohn's disease. Gut. 1969; 10(7): 549-54.

9. Dudeney TP. Crohn's disease of the mouth. Proc R Soc Med. 1969; 62(12): 1237.

10. Lankarani KB, Sivandzadeh GR, Hassanpour S. Oral manifestation in inflammatory bowel disease: a review. World $\mathrm{J}$ Gastroenterol. 2013; 19(46): 8571-9.

11. Greenstein AJ, Janowitz HD, Sachar DB. The extra-intestinal complications of Crohn's disease and ulcerative colitis: a study of 700 patients. Medicine (Baltimore). 1976; 55(5): 401-12.

12. Pittock S, Drumm B, Fleming P et al. The oral cavity in Crohn's disease. J Pediatr. 2001; 138(5): 767-71. 
13. Harty S, Fleming P, Rowland $\mathrm{M}$ et al. A prospective study of the oral manifestations of Crohn's disease. Clin Gastroenterol Hepatol. 2005; 3(9): 886-91.

14. Rowland M, Fleming P, Bourke B. Looking in the mouth for Crohn's disease. Inflamm Bowel Dis. 2010; 16(2): 332-7.

15. Mijandrusić-Sincić B, Licul V, Gorup L, Brncić N, Glazar I, Lucin K. Pyostomatitis vegetans associated with inflammatory bowel disease-report of two cases. Coll Antropol. 2010; 34(Suppl 2): 279-82.

16. Galbraith SS, Drolet BA, Kugathasan S, Paller AS, Esterly NB. Asymptomatic inflammatory bowel disease presenting with mucocutaneous findings. Pediatrics. 2005; 116(3): $439-44$.

17. Daley TD, Armstrong JE. Oral manifestations of gastrointestinal diseases. Can J Gastroenterol. 2007; 21(4): 241-4.

18. Plauth M, Jenss H, Meyle J. Oral manifestations of Crohn's disease. An analysis of 79 cases. J Clin Gastroenterol. 1991; 13(1): 29-37.

19. Williams AJ, Wray D, Ferguson A. The clinical entity of orofacial Crohn's disease. Q J Med. 1991; 79(289): 451-8.

20. Snyder MB, Cawson RA. Oral changes in Crohn's disease. J Oral Surg. 1976; 34(7): 594-9.

\author{
Correspondence to /Autor za korespondenciju \\ Miranda Muhvić-Urek, PhD, DMD \\ Department of Oral Medicine \\ Dental Clinic, University Hospital Rijeka, Croatia \\ Krešimirova 40, \\ Rijeka HR-51000, Croatia, \\ Tel: ++38551345634; \\ Fax: ++38551345630; \\ Emal:miranda_um@hotmail.com \\ miranda.muhvic.urek@medri.uniri.hr
}

21. Schiller KF, Golding PL, Peebles RA, Whitehead R. Crohn's disease of the mouth and lips. Gut. 1971; 12(10): 864-5.

22. Katz J, Shenkman A, Stavropoulos F, Melzer E. Oral signs and symptoms in relation to disease activity and site of involvement in patients with inflammatory bowel disease. Oral Dis. 2003 ; 9(1): 34-40.

23. Manchno Franch A, Jimenez Soriano Y, Sarrion Perez MG. Dental management of patients with inflammatory bowel disease. J Clin Exp Dent. 2010; 2(4): 191-5.

24. Ficarra G, Cicchi P, Amorosi A, Piluso S. Oral Crohn's disease and pyostomatitis vegetans. An unusual association. Oral Surg Oral Med Oral Pathol. 1993; 75(2): 220-4.

25. Trost LB, McDonnell JK. Important cutaneous manifestations of inflammatory bowel disease. Postgrad Med J. 2005; 81(959): 580-5.

26. Sollecito TP, Stoopler ET, Rangarajan S, Pinto A. Pyostomatitis vegetans and orofacial granulomatosis: a case report and review of the literature. Internet J Anesthesiol. 2003; 14(2): 1-5.

27. Mijandrušić Sinčić B, Vince A. [Screening for opportunistic infections and vaccination before introduction of biologic therapy]. Acta Med Croatica. 2013; 67(2): 165-70. 